Enhancement of thrombolytic efficacy of ti ssue type pl asminogen acti vat or by adj uvants in the gui nea pig thrombosi s model

\begin{tabular}{|l|l|}
\hline 著者 & 西山 浩史 \\
\hline 杂隹誌名 & 浜松医科大学学報. 学位授与記録 \\
\hline 巻 & 14 \\
\hline ○゚ージ & $76-77$ \\
\hline 発行年 & $1997-01$ - 10 \\
\hline URL & ht $\mathrm{p}$ : / / hdl . handl e. net /10271/1522 \\
\hline
\end{tabular}


学位論文の内容の要旨及び論文審査の結果の要旨

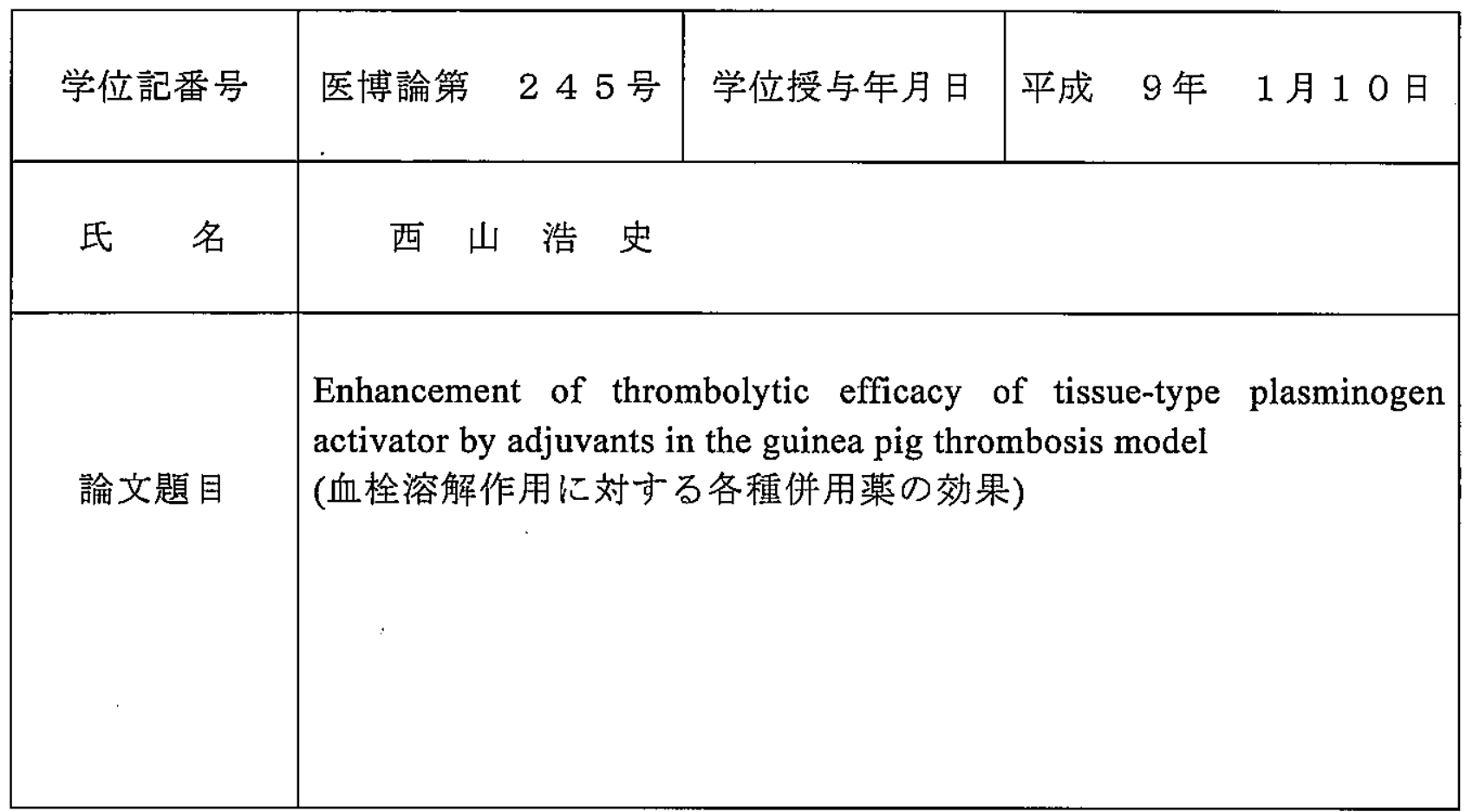


博士(医学) 西山浩 史

觛文題目

Enhancement of thrombolytic efficacy of tissue-type plasminogen activator by adjuvants in the guinea pig thrombosis model

(血栓溶解作用に対する各種併用薬の効果)

\section{融文の内容の 要旨}

近年急性心筋梗塞などの知患における血栓溶解潦法は高い有効性が報告されている。しかし、血栓溶 解後の再閉塞は臨床において重要な問題となっているが、血管再閉塞のメカニズムは未だ明らかになっ ていない。そこで今回我々は、ローズベンガルと540nm の緑色光による光增感反応誘発内皮伤害性の モルモット大腿動脈血栓モデルを用いて、遺伝子組み替え組織型プラスミノーゲンアクチベータ（rtPA）による血栓溶解後の血管再閉塞のメカニズムについて検討した。

実験方法は、麻酔下モルモット暊静脈にダブルルーメンカテーテルを留頤後、右大腿動脈にバルスド ップラー血流計を装着し、大眼動脈血流を測定した。血栓はローズベンガル $(10 \mathrm{mg} / \mathrm{kg})$ 静脈内投与と 540 $\mathrm{nm}$ の緑色光（55万ルクス）を右大腿動脈に照射して形成した。血栓形成は大腿動脈血流の完全停止を 指標とした。血栓形成30分後に自然再開通のないことを確認した後、 $\mathrm{rt}-\mathrm{PA}(1 \mathrm{mg} / \mathrm{kg} / 30 \mathrm{~min})$ を静脈 内に 30 分間持続投与し、投与開始 2 時間後まで大腿動脈血流を測定し、再開通時間、開通期間、 intermittent reflow の数、血流変化を測定した。TXA 2 受容体拮抗薬バビプロスト（VAPI）は、It-PA の持続投与開始と同時に静脈内に $0.3 \mathrm{mg} / \mathrm{kg}$ 投与する同時投与群と血栓溶解剂との併用による出血を考慮 し、rt-PA の作用が消失する $\mathrm{rt}-\mathrm{PA}$ 投与終了 30 分後に投与する後投与群の 2 群を行った。抗トロンビ ン薬のアルガトロバンは（ARG）はVAPI と同様 $\mathrm{rt}-\mathrm{PA}$ の投与と同時に $200 \mu \mathrm{g} / \mathrm{kg} / \mathrm{min}$ の用量を 2 時 間持続投与する同時投与群と $\mathrm{rt}-\mathrm{PA}$ 投与終了 30 分後から 1 時間持続投与する後投与群の 2 群を行った。 ロイコトリエン類生合成酵索阻害薬の MK-886 (MK) は、rt-PAの持続投与開始と同時に $3 \mathrm{mg} / \mathrm{kg}$ を 腹腔内投与した。また、血栓溶解24時間後の再閉塞に対する各薬物の影響を検討するため、各測定項目 終了後手術部位を檤合し、覚醒下モルモットにVAPI 投与群の 2 群には VAPI $3 \mathrm{mg} / \mathrm{kg}$ の経口投与、ARG 投与の 2 群には ARG $100 \mathrm{mg} / \mathrm{kg}$ の皮下投与を 1 日 2 回、MK 投与群には MK $30 \mathrm{mg} / \mathrm{kg}$ の経口投与を行った。 さらに、血栓溶解24時間後に再閉塞した血管の組織学的な検討も行った。

$\mathrm{rt}$-PA を単独投与した群に比較して、VAPI 同時投与群では、血栓溶解急性期の血栓溶解作用の增強 と intermittent reflow の抑制、さらに血栓溶解24時間後の再閉塞を抑制した。しかし、VAPI 後投与群 は、24時間後の再閉塞を抑制しなかった。一方 ARG 同時投与群は、血栓溶解急性期において、開通期 間の延長効果のみが認められたが、intermittent reflow は抑制しなかった。しかし、24時間後の再䦥塞 は抑制した。また ARG 後投与群は24時間後の再閉塞は抑制しなかった。MK 投与群は、血栓溶解急性 期において、血栓溶解作用には影響を与えなかったが、24時間の再閉塞を抑制した。さらに、24時間後 に再閉塞した血管は赤色血栓であり、光学顕微鏡像において血栓内への白血球の漫潤がみられていた。 このモデルにおいて、急性期の rt-PA による血栓溶解効果を VAPI が著明に増強し、 intermittent reflow も完全に抑制した。この抑制作用は ARG と MK にはみられなかった。以上のことから、血栓溶 解急性期に出現する intermittent reflow は TXA 2 妿関与していると思われる。また、VAPI と ARG は $\mathrm{rt}$ -PA と同時に併用しないと、血栓溶解24時間後の再閉塞抑制作用が減弱した。このことから、血小板 および凝固系以外の他の因子が血栓溶解24時間後の再閉塞に関与する可能性が示唆され、これらの因子 
の一つとして光䫓像およびMK の24時間後の再閉塞抑制作用から、白血球の関与が示唆された。

\section{編文審査の結果の要旨}

急性心筋梗塞等における血栓溶解療法は高い有奻性が報告されている。しかし血栓溶解後の血管再閉 塞が問題になっており、そのメカニスムは未だ明らかにされていない。

(対象及び方法)

申請者は、ローズベンガルと540nm の緑色光による光增感反応誘発血管内皮等害を利用したモルモ ットの大腿動脈血栓モデルを用いて、遗伝子組み替え組織型ブラスミノーゲンアクチベータ（rt-PA） による血栓溶解後の血管再閉塞に対するトロンボキサン $\mathrm{A}_{2}$ 受容体拮抗薬バビロスト、抗トロンビン薬 アルガトロバン及びロイコトリエン類生合成酵素阻害薬 MK-886の影警を調ベ、急性期の血管再閉塞 のメカニスムを推测した。

(結 果)

rt-PA 投与後、血拴溶解とこれに続く間欠性閉塞及び24時間後の再閉塞が観察された。バビプロス トは間久性閉塞と24時間後の再閉塞を抑制した。アルガトロバンは間久性閉塞を有意に抑制しないが、24 時間後の再閉塞を抑制した。MK-886は24時間後の再閉塞のみを抑制した。

(結論)

これらの結果から、申請者は血栓溶解に続く間欠性閉塞にはトロンボキサン $\mathrm{A}_{2}$ が関与し、24時間後 の再閉塞には血小板系、凝固系以外に白血球も関与するという新しい考え方を提示した。

本研究では、血栓溶解療法の問題点である溶解後再閉塞について、そのメカニズムに関する重要な知 見が得られ、更に新しい抗血小板薬、抗凝固薬の有効性が示唆された。これらの成果は今後の血栓溶解 療法の向上に寄与する可能性があるものとして評価された。また、従来の血栓モデルよりも侵留が少な いモデルを利用し、太t-PAによる血栓溶解後の再閉塞のモデルを作成したことに対して、その実験方 法の独創性も評価されだ。

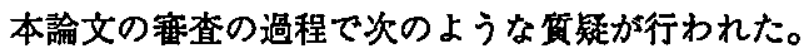

1) rt-PA を投与しない場合の自然再開通はどれだけあるか

2）血栓形成部位と血流モニタ一の位膡関係はどのようになっているか

3）血流の測定法について

4 ）この血栓モデルはヒトのどのような血栓症を想定しているか

5）この研究でモルモットを使用している理由

6） rt-PA 投与後の再閉塞の発生頻度はヒトの場合と比較してどうか

7) アルガトロバン、バビプロストの再開塞抑制の機序

8）閉塞部迋位側の微小多発塞栓の、再閣塞に対する影響について

9) 白血球がどのように再閉塞に関与するのか

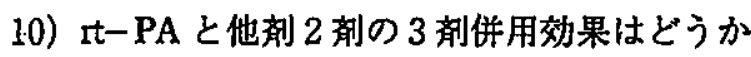

11）アルガトロバンが rt-PAによる出血を增大させる機序は

12）薬物の投与量を変えて検討したか

これらの質問に対し申請者の解答は適切であり、問題点も十分理解しており、博士（医学）の学位論 文にふさわしいと審查員全員一致で判定した。

論文審查担当者 主查 教授 橋 本 久 邦

副查 教授 寺尾俊彦 副査 助教授 浦 野 哲 盟 